\title{
Microsurgical reconstruction in pediatric patients: a series of 30 patients
}

\author{
Arzu Akçal, M.D., ${ }^{1}$ Semra Karşıdağ, M.D., ${ }^{2}$ Deniz Özgür Sucu, M.D., ${ }^{2}$ \\ Gürsel Turgut, M.D., ${ }^{2}$ Kemal Uğurlu, M.D. ${ }^{2}$ \\ ${ }^{1}$ Deparment of Plastic and Reconstructive Surgery, Akdeniz University Faculty of Medicine, Istanbul; \\ ${ }^{2}$ Deparment of Plastic and Reconstructive Surgery, Sisli Etfal Training and Research Hospital, Istanbul
}

\begin{abstract}
BACKGROUND: Free flap surgery in the pediatric population has gained widespread acceptance regarding its technical utility and reliability. Initial concerns as to the feasibility and reliability of the procedure in children were resolved over time.

METHODS: Thirty children (I5 boys, 15 girls) were treated in Sisli Etfal Training and Research Hospital, Plastic and Reconstructive Surgery Clinic. Their mean age was 10.8 years. Defects were located on the lower extremity $(n=22)$, head and neck ( $n=5)$ and upper extremity $(n=3)$. The etiologies of the defects included vehicle accident, sequelae of burn, traumatic contractures, crush injury, epulis in the maxilla, and gunshot wound.

RESULTS: The free flaps performed in our series were latissimus dorsi muscle flap, combined latissimus dorsi and serratus muscle flaps, serratus anterior muscle flap, cross latissimus dorsi muscle flap, scapular osteomyocutaneous flap, parascapular fasciocutaneous flap, fibular osteocutaneous flap, anterolateral thigh flap, medial circumflex femoral artery perforator flap, and crista iliaca osteocutaneous flap.
\end{abstract}

CONCLUSION: The advantages of free flaps in children, which include better adaptation of the flap growth and better learning capacity of the children, provide the surgeon with more satisfactory functional and aesthetic results.

Key words: Free flap, pediatric population, perforator flap.

\section{INTRODUCTION}

Free flaps are a useful reconstructive option in the management of soft tissue defects, even in the pediatric population. ${ }^{[1,2]}$ Microsurgery was first performed in children in the mid 1970s, a few years after performing the procedure in adults. The first publications ${ }^{[1,2]}$ were sporadic, suggesting the microsurgical transfer was possible in children. ${ }^{[3,4]}$ Free flap surgery in the pediatric population has gained widespread acceptance after doubts about the technical utility and reliability of the procedure were resolved. Initial concerns as to the feasibility and

Address for correspondence: Arzu Akçal, M.D.
Akdeniz Üniversitesi, Plastik ve Rekonstrüktif Cerrahi ABD., Kat:
2 Dumlupınar Bulvarı 07058 Kampüs, Antalya 07058 Antalya, Turkey
$\begin{array}{ll}\text { Tel: }+90242 \text { - } 2496000 \quad \text { E-mail: ozcanarzu79@yahoo.com } \\ \text { Qucik Response Code } & \text { Ulus Travma Acil Cerr Derg } \\ \end{array}$
$\begin{array}{ll}\text { doi: } 10.5505 / \text { tjtes.2013.095I5 } \\ \end{array}$

reliability of the procedure in children were readily overcome by the fact that the relative size of the pedicle vessels is larger than those in adults. ${ }^{[4]}$ In absolute size, though, the vessels can be rather small, which means that flaps with sizable pedicles and a reliable anatomy were preferentially selected. However, different authors have published successful results of free tissue transfers in children in various clinical situations, proving the utility and effectiveness of the microsurgical procedure, with a success rate comparable to that of the adult group. ${ }^{[5,6]}$

Perforator flaps have the advantage of well-known, sizable source vessels. Furthermore, their pedicles have enough length to allow for anastomoses out of the site of injury, and the skin islands cover the same area as conventional myocutaneous flaps, without any donor-site morbidity. The perforator vessels can be relatively small in children, though their relative size compared with the size of the child's body is greater than that in adults. ${ }^{[7]}$

Our current study reports a series of 30 free flaps performed in children for various reconstructions. Seven of these flaps were perforator flaps, which are valuable reconstructive options even in pediatric patients. 


\section{MATERIALS AND METHODS}

From January 1997 to January 2010, 30 children (I5 boys, 15 girls) were treated in Sisli Etfal Training and Research Hospital, Plastic and Reconstructive Surgery Clinic. The children were assessed according to their age, sex, etiology of the defects, location of the defects, operation time, type of flap, recipient vessels, postoperative care, postoperative complications, follow-up period after the operation, and the child's growth. The types of flap and anastomosis in the patients who developed complications were also examined. Seven patients reconstructed with perforator flap were investigated according to age, sex, etiology of the defect, localization of the defect, flap type, recipient artery, operation time, and complications.

\section{RESULTS}

From January 1997 to January 2010, 30 children (I5 boys, 15 girls) were treated. Their mean age was 10.8 (range, 2-17) years. Defects were located on the lower extremity in 22 (73.3\%), upper extremity in $3(10 \%)$, and head and neck in 5 (16.6\%). The etiologies of the defects included vehicle accident $(n=16)$, sequelae of burn $(n=7)$, traumatic contractures $(n=3)$, crush injury $(n=2)$, epulis in the maxilla $(n=1)$, and gunshot wound $(n=I)$. The free flaps performed in our series included latissimus dorsi muscle flap $(n=7)$, combined latissimus dorsi and serratus muscle flaps $(n=2)$, serratus anterior muscle flap $(n=4)$, cross latissimus dorsi muscle flap $(n=1)$, scapular osteomyocutaneous flap $(n=l)$, parascapular fasciocutaneous flap $(n=6)$, fibular osteocutaneous flap $(n=I)$, anterolateral thigh flap $(n=6)$, medial circumflex femoral artery perforator flap $(n=I)$, and crista iliaca osteocutaneous flap $(n=I)$. The flaps used to cover the defects are shown in Table I.

The mean size of the soft tissue defect was $10 \times 8 \mathrm{~cm}$ on the lower extremity, $6 \times 4 \mathrm{~cm}$ on the upper extremity and $6 \times 5$ $\mathrm{cm}$ on the head and neck. Free flaps that were used to cover defects due to vehicle accidents and crush injuries were performed often in the first week of injury.

All patients were operated under general anesthesia. All anastomoses were performed with interrupted sutures of $9-0$ or 10-0 nylon, end-to-side on the artery and end-to-end on the deep vein. Mean operating time was 6 hours. Broad spectrum antibiotics were given intravenously for 3-5 days according to the type of injury. Bed rest and prudent monitoring of temperature, color, capillary refill, and Doppler examinations were provided for 10 days.

The success rate of free tissue transfer was $93.75 \%$ (30 of 32). The parascapular fasciocutaneous flap that was used to cover a traumatic defect on the scalp was lost with venous occlusion on the 7th postoperative day. The serratus anterior muscle flap that was used to cover the defect occurring after burn contracture release on the dorsum of the foot failed due to arterial insufficiency. Partial flap necrosis was seen in two flaps (I parascapular fasciocutaneous flap used to cover the defect on the dorsum of the foot and I latissimus muscle flap on the lateral aspect of the foot). These two patients underwent reanastomosis in the first 24 hours and the flaps were salvaged. Minor complications, including partial flap losses of less than $10 \%$ of the surface and small wound dehiscence, were noted in about $20 \%$ of our patients. These complications were treated conservatively or could be resolved by secondary suturing. The mean follow-up period was 49 months.

Seven perforator flaps were performed in the lower extremity defects. Six of them were anterolateral thigh flap and one was medial circumflex femoral artery perforator flap. The mean age of these patients was 10.8 years. We did not observe any partial or total flap loss. Small wound dehiscence was seen in one of the anterolateral thigh flaps. We did not determine any regression in child development during our follow-up period.

\section{Representative Cases}

Case 1- A five-year-old boy was admitted to the emergency department with avulsion of the entire leg skin and exposure of the tibia due to vehicle accident. Fracture stabilization was provided with external fixator. After serial debridements, the size of the defect consisted of the entire leg and heel. Combined latissimus dorsi and serratus anterior muscle flaps were preferred due to the large size of the defect (Fig. Ia-d). Free flap transfer was performed on the 10th day of injury. The anastomosis was performed to the posterior tibial artery in end-to-side fashion. Two concomitant venous anastomoses were performed. Split-thickness skin grafts from the posterolateral thigh were transferred for flap coverage. Flap monitoring was performed by means of capillary refill, temperature, and Doppler ultrasound. Total flap survival with no tissue loss occurred. One year after the free flap transfer, the external fixator was removed and tibiofibular syndesmosis was performed (Fig. le, f).

Case 2- A I 3-year-old girl was admitted to our department with epulis lesion of the maxilla. After the lesion was excised with tumor free margins, a free vascularized crista iliaca flap was used to reconstruct the maxilla and hard palate (Fig. 2a-d). The anastomosis was performed to the superficial temporal artery, and concomitant venous anastomosis was performed. Flap monitoring was performed by means of capillary refill, temperature, and Doppler ultrasound. Total flap survival with no tissue loss occurred. Six months after the free flap transfer, all the mucosal surfaces were intact (Fig. $2 e, f)$.

Case 3- A 13-year-old boy was admitted to our department due to burn contracture on the plantar area of his right foot. 
Table I. Study data

\begin{tabular}{|c|c|c|c|c|c|c|}
\hline & No & Gender & Age & Location of the defect & Flap type & Complication \\
\hline \multicolumn{7}{|c|}{ Traumatic contractures } \\
\hline & 1 & Female & 10 & Right foot & Anterolateral thigh & \\
\hline \multirow[t]{9}{*}{ Wound dehiscence } & 2 & Female & 16 & Right elbow & Parascapular & Wound dehiscence \\
\hline & 3 & Female & 5 & Left foot & Parascapular & Burn contracture \\
\hline & 4 & Female & 17 & Neck & Anterolateral thigh & \\
\hline & 5 & Female & 17 & Right cruris & Cross-latissimus & \\
\hline & 6 & Male & 9 & Neck & Parascapular & \\
\hline & 7 & Male & 15 & Right heel & Anterolateral thigh & Wound dehiscence \\
\hline & 8 & Female & 17 & Left foot & Serratus & \\
\hline & 9 & Male & 16 & Right hand & Serratus & \\
\hline & 10 & Female & II & Left foot & Serratus & Total necrosis \\
\hline \multicolumn{7}{|l|}{ Traumatic defect } \\
\hline & II & Male & 8 & Left foot & Anterolateral thigh & \\
\hline & 12 & Female & 3 & Left heel & Latissimus & \\
\hline & 13 & Male & 17 & Left heel & Latissimus & \\
\hline & 14 & Male & II & $\begin{array}{l}\text { Right foot-Ist metacarpal } \\
\text { defect }\end{array}$ & Free fibula & \\
\hline & 15 & Male & 5 & Right cruris & Latissimus+serratus & \\
\hline & 16 & Female & 13 & Left foot-dorsum & Anterolateral thigh & \\
\hline & 17 & Male & 13 & Right foot & Anterolateral thigh & \\
\hline & 18 & Male & 4 & Scalp & Parascapular fasciocutaneous & Total necrosis \\
\hline & 19 & Male & 2 & Left cruris & Latissimus & \\
\hline & 20 & Female & 7 & Right cruris & Latissimus & \\
\hline & 21 & Male & 6 & Right foot & Latissimus & Partial necrosis \\
\hline & 22 & Female & 15 & Left heel & Serratus & \\
\hline & 23 & Male & 8 & Right dorsum of foot & Latissimus & \\
\hline & 24 & Female & 14 & Left arm-forearm & Latissimus-serratus & \\
\hline & 25 & Male & 12 & Left foot & Parascapular & \\
\hline & 26 & Female & 9 & Right cruris & Latissimus & \\
\hline & 27 & Female & 13 & Left foot & Parascapular & Partial necrosis \\
\hline & 28 & Male & 6 & Right foot & $\begin{array}{l}\text { Medial circumflex femoral } \\
\text { artery perforator flap }\end{array}$ & \\
\hline \multicolumn{7}{|l|}{ Gunshot injury } \\
\hline & 29 & Male & 12 & Mandible & Scapular osteomyocutaneous & \\
\hline \multicolumn{7}{|l|}{ Epulis } \\
\hline & 30 & Female & 13 & Maxilla & Crista iliaca & \\
\hline
\end{tabular}

After the release of the contracture, anterolateral thigh flap was performed to cover the plantar surface of the foot. The anastomosis was performed to the tibialis posterior artery in end-to-side fashion. Two concomitant venous anastomoses were performed. Flap monitoring was performed by means of capillary refill, temperature, and Doppler ultrasound. Total flap survival with no tissue loss occurred. He could wear his shoes comfortably by the end of one year (Fig. 3a-e).

\section{DISCUSSION}

In recent years, there has been significant doubt about the technical versatility and feasibility of microsurgery in children. Initial concerns as to the feasibility and reliability of these procedures were overcome rapidly. ${ }^{[3,4,7]}$ Microsurgeries succeed in children more often than in adults for two reasons. The first issue is that the relative size of the vessels when 

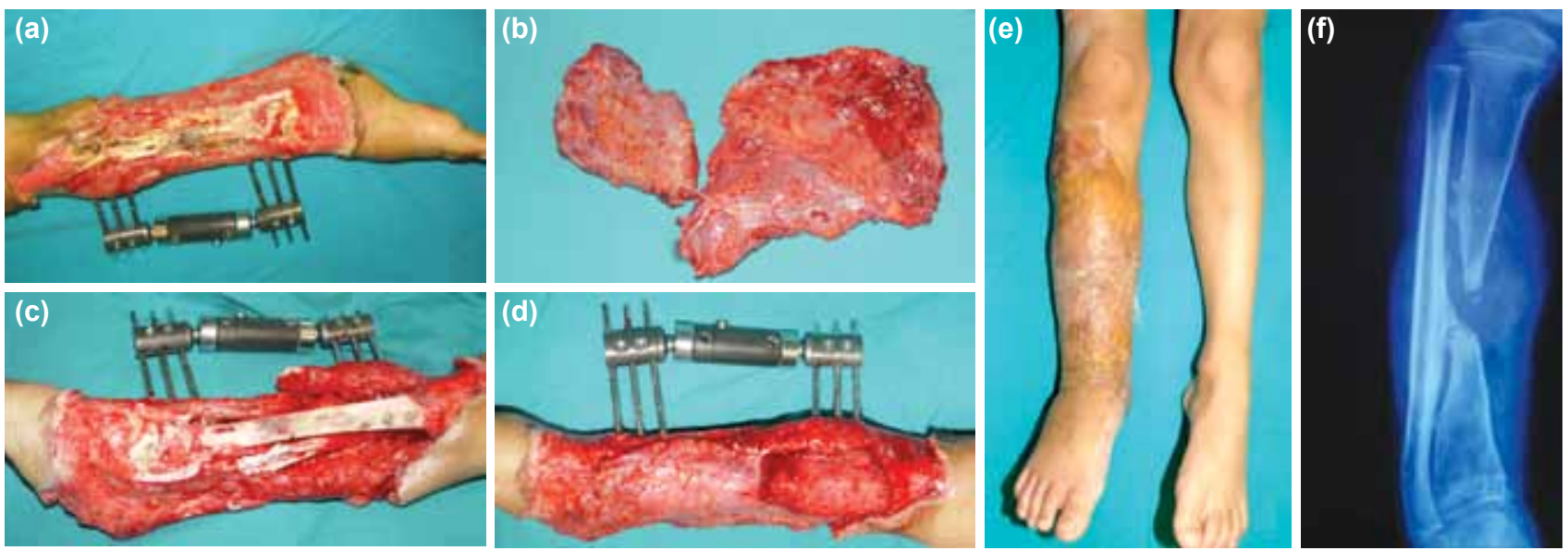

Figure 1. (a) Avulsion of the entire leg skin and exposure of the tibia due to vehicle accident. Fracture stabilization was provided with external fixator. After the serial debridements, the size of the defect consisted of the entire leg and heel. (b) Combined latissimus dorsi and serratus anterior muscle flaps were harvested due to the large size of the defect. (c) After the serial debridements, the size of the defect consisted of the entire leg and heel. (d) The anastomosis of the combined latissimus dorsi and serratus anterior muscle flap was performed to the posterior tibial artery in end-to-side fashion. Two concomitant venous anastomoses were performed. (e) Anterior view of the leg at postoperative one year. (f) One year after the free flap transfer, the external fixator was removed, and tibiofibular syndesmosis was performed.

compared with the child's body is greater than that of adults, and the second issue is that children have minimal comorbidities like smoking, diabetes, hypertension, or peripheral vessel disease. In absolute size, though, the vessels can be rather small, which means that flaps with sizable pedicles and a reliable anatomy were preferentially selected. Parry et al. ${ }^{[4]}$ stated that vascular spasm and atherosclerosis of the vessels are not issues in children.
The first flaps that were performed in children were skin flaps, which are not used today. Skin flaps are no longer preferred by surgeons due to the rather variable and small vasculature.despite the low donor site morbidity. ${ }^{[9]}$ Irigaray described the inclusion of an anterior strip of the latissimus dorsi to increase the reliability of the flap, which could mean a myocutaneous or even the first compound latissimus dorsi flap. The flap in use in the early days of microsurgery was the
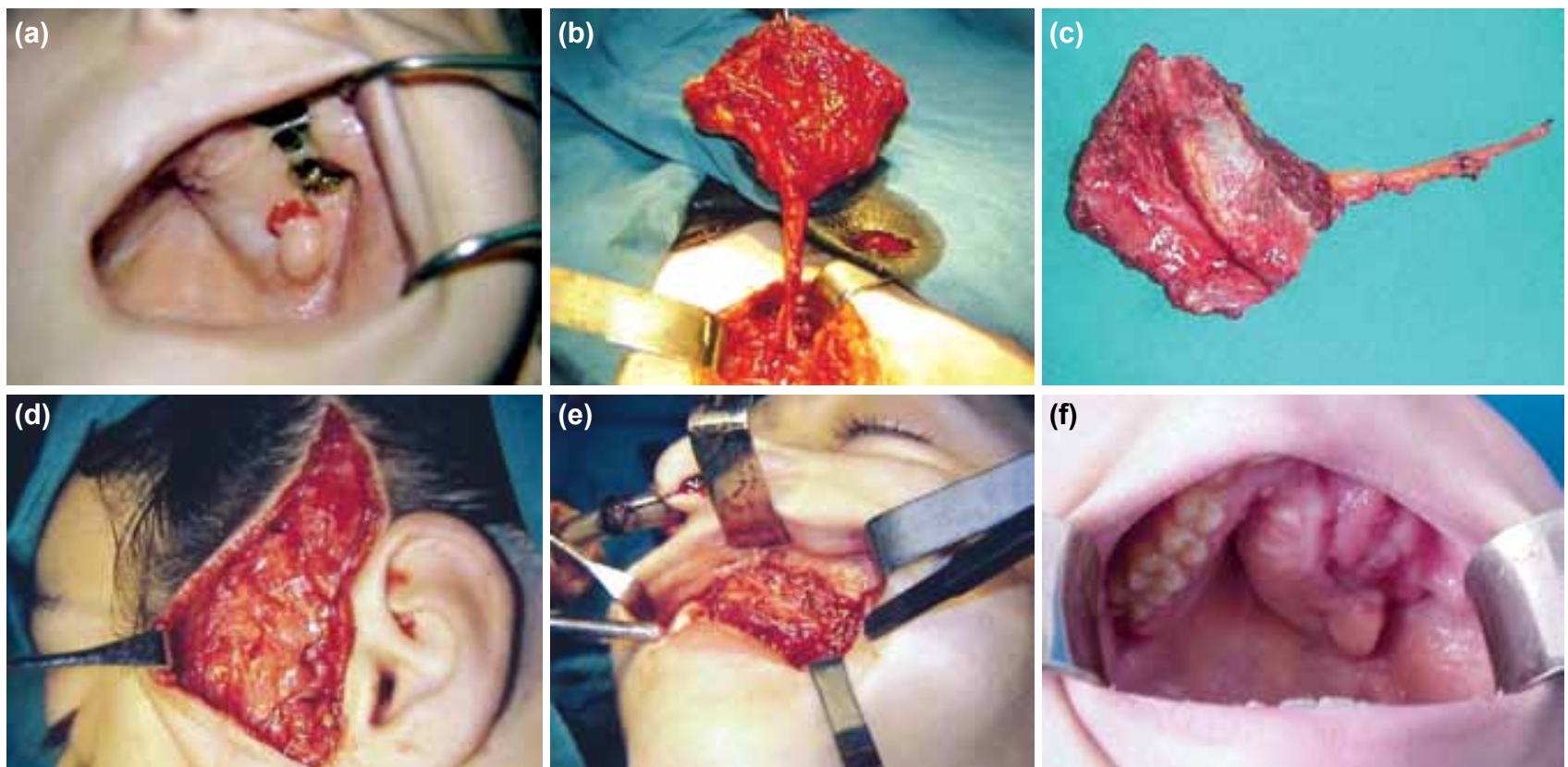

Figure 2. (a) A 13-year-old girl was admitted to our department with epulis lesion in the maxilla. (b, c) Free vascularized crista iliaca flap was used to reconstruct the maxilla and hard palate. (d) The anastomosis was performed to the superficial temporal artery and concomitant venous anastomosis was performed. (e) Free vascularized crista iliaca flap was adapted to the maxilla and hard palate. (f) View at the postoperative 6th month - all the mucosal surfaces were intact. 

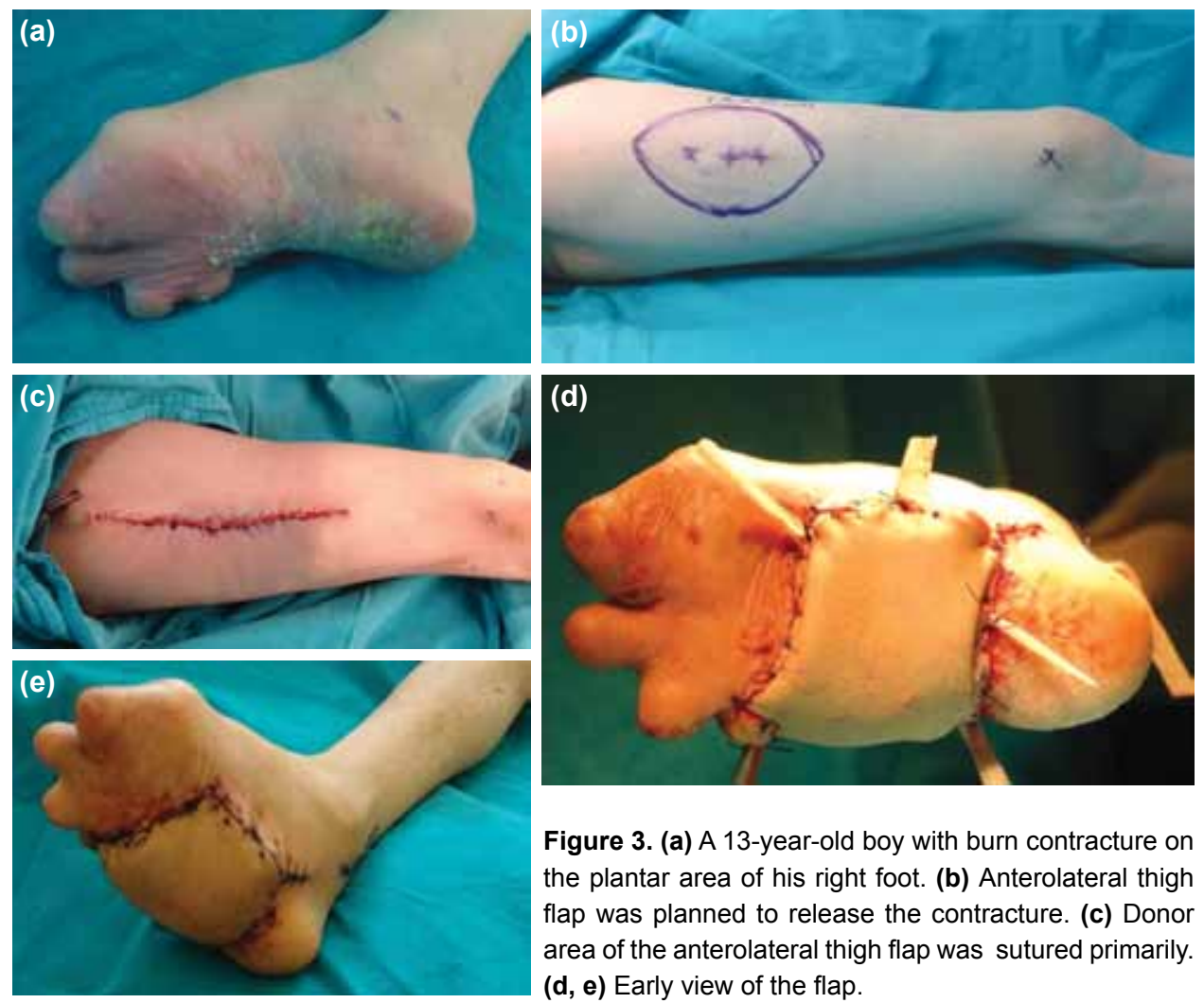

Figure 3. (a) A 13-year-old boy with burn contracture on the plantar area of his right foot. (b) Anterolateral thigh flap was planned to release the contracture. (c) Donor area of the anterolateral thigh flap was sutured primarily. (d, e) Early view of the flap.

lateral thoracic flap ${ }^{[1]}$ as reported by Irigaray et al. ${ }^{[9]}$ In the same regard, we used to perform flaps dependent on the subscapular artery system. In $61 \%$ of our patients, we chose to harvest the free flap from this system for two reasons. First, the larger and more reliable thoracodorsal artery increased the success of the operation and second, the donor site scar could be concealed underneath clothes.

In the perforator era, we started to harvest perforator flaps due to their minimal donor site morbidity. We thus harvested anterolateral thigh flaps in six of 32 patients and one medial circumflex femoral artery flap. There are a limited number of articles reporting perforator flaps in children, and the medial circumflex femoral perforator flap is not one of the flaps that might be chosen as a primary free flap. However, we performed the medial circumflex femoral artery perforator flap in a seven-year-old boy, and we did not see any partial or total flap necrosis in the early and late period. ${ }^{[10]}$ Today, we have begun to perform the perforator flaps because of the minimal donor site scar and their proven technical feasibility and reliability.

Most pediatric trauma series, as in ours, indicate that these injuries arise most commonly from road traffic accidents, and that males are more often involved than females. The choice of the free flap in pediatric reconstructive surgery seems to depend essentially on the size of the defect and the surgeon's preferences. In our series, we decided to harvest combined latissimus dorsi and serratus muscles flaps to cover the entire leg in two cases, and we covered large and dirty defects with latissimus dorsi muscle flaps. Our success rate approached $100 \%$ with these large muscle flaps due to their large caliber vessels.

Vascular integrity in children (absence of atheroma) is certainly one of the essential reasons for the high success rates of the pediatric series. Although vessel diameter in the child is smaller than in the adult, no major technical difficulties were encountered in our series. Even though $20 \%$ of our series consisted of perforator flaps, our success rate was almost $94 \%$, which was consistent with the reported success rates of the other series ( $85 \%$ and $90 \%$ ). However, while the success rate with the perforator flap is given as $96 \%$ in the literature8, we did not see any partial or total flap failure with perforator flaps in our series.

The two major criticisms of free flaps are the deficit at the donor site and possible effects on normal growth. Canales et al. ${ }^{\left[{ }^{[1]}\right]}$ and Chiang et al. ${ }^{[12]}$ found no growth disturbances at the donor or injury site over a longer follow-up period. $\mathrm{Yu}^{\left[{ }^{[1]}\right]}$ also showed that bilateral harvesting of the latissimus dorsi in children can be performed without long-term effects. These problems were not encountered in our series, although the follow-up period may be too short (mean, 49 months).

The advantages of the free flaps in children included better adaptation of the flap growth and better learning capacity of the children, which provided the surgeon with more satisfactory functional and aesthetic results. 
We can suggest to all clinics with experienced microsurgical teams that free flaps can be used safely in pediatric patients despite the technical difficulties.

\section{Conflict of interest: None declared.}

\section{REFERENCES}

1. Harii K, Ohmori K. Free groin flaps in children. Plast Reconstr Surg 1975;55:588-92.

2. Ohmori K, Harii K, Sekiguchi J, Torii S. The youngest free groin flap yet? Br J Plast Surg 1977;30:273-6.

3. Van Beek AL, Wavak PW, Zook EG. Microvascular surgery in young children. Plast Reconstr Surg 1979;63:457-62.

4. Parry SW, Toth BA, Elliott LF. Microvascular free-tissue transfer in children. Plast Reconstr Surg 1988;81:838-40.

5. Shenaq SM, Dinh TA. Pediatric microsurgery. Replantation, revascularization, and obstetric brachial plexus palsy. Clin Plast Surg 1990;17:77-83.

6. Duteille F, Lim A, Dautel G. Free flap coverage of upper and lower limb tissue defects in children: a series of 22 patients. Ann Plast Surg
2003;50:344-9.

7. Van Landuyt K, Hamdi M, Blondeel P, Tonnard P, Verpaele A, Monstrey S. Free perforator flaps in children. Plast Reconstr Surg 2005;116:15969.

8. Iwaya T, Harii K, Yamada A. Microvascular free flaps for the treatment of avulsion injuries of the feet in children. J Trauma 1982;22:15-9.

9. Irigaray A, Roncagliolo A, Fossati G. Transfer of a free lateral thoracic flap in a child. Plast Reconstr Surg 1979;64:259-63.

10. Karsidag S, Akcal A, Yesiloglu N, Ugurlu K. Medial circumflex femoral artery perforator flap in a seven-year-old boy for a degloving ankle injury: a case report in immediate reconstruction. The Foot and Ankle Online Journal 2010;3:1. Available at: http://faoj.org/2010/05/01/may-2010/.

11. Canales F, Lineaweaver WC, Furnas H, Whitney TM, Siko PP, Alpert BS, et al. Microvascular tissue transfer in paediatric patients: analysis of 106 cases. Br J Plast Surg 1991;44:423-7.

12. Chiang YC, Jeng SF, Yeh MC, Liu YT, Chen HT, Wei FC. Free tissue transfer for leg reconstruction in children. Br J Plast Surg 1997;50:33542.

13. Yu ZJ. The use of bilateral latissimus dorsi myocutaneous flaps to cover large soft tissue defects in the lower limbs of children. J Reconstr Microsurg 1988;4:83-8.

\section{KLINIK ÇALIŞMA - ÖZET}

\section{Çocuk hastalarda mikrocerrahi rekonstrüksiyon: 30 olguluk seri}

\section{Dr. Arzu Akçal, ${ }^{1}$ Dr. Semra Karşıdağ, ${ }^{2}$ Dr. Deniz Özgür Sucu, ${ }^{2}$ Dr. Gürsel Turgut, ${ }^{2}$ Dr. Kemal Uğurlu ${ }^{2}$}

${ }^{1}$ Akdeniz Üniversitesi, Plastik ve Rekonstrüktif Cerrahi Anabilim Dalı, Antalya;

${ }^{2}$ Şişli Etfal Eğitim ve Araştırma Hastanesi, Plastik ve Rekonstrüktif Cerrahi Kliniği, Istanbul

AMAÇ: Pediatrik popülasyonda serbest doku aktarımı teknik yararılı̆̆ı ve güvenililirliği nedeni ile geniş kabul görmektedir. Cerrahi işlemin uygunluğu ve güvenililirliğini içeren başlangış süpheleri artık giderilmiştir.

GEREÇ VE YÖNTEM: Otuz çocuk hasta ( 15 erkek, I 5 kız) Şişli Etfal Eğitim ve Araştırma Hastanesi'nde serbest doku aktarımı uygulanarak tedavi edildi. Hastaların defektleri alt ekstremitede $(n=22)$, baş ve boyunda $(n=5)$ ve üst ekstremitede $(n=3)$ yerleşimli idi. Defektlerin etiyolojileri araba kazalarını, yanık sekellerini, travmatik kontraktürlerini, ezilme yaralanmalarını, maksillada epulisi ve ateşli silah yaralanmalarını içerdi.

BULGULAR: Çalısmamızda aktarılan serbest dokular latissimus dorsi kas flebi, kombine latissimus dorsi ve serratus kas flepleri, serratus anterior kas flebi, çapraz latissimus dorsi kas flebi, skapüler osteomyokutanöz flebi, paraskapüler fasyokutanöz flebini, fibuler osteokutanöz flebi, anterolateral uyluk flebini ve medial sirkumfleks femoral arter perforatör flebi ve crista iliaca osteocutanöz flebini içeriyordu.

TARTIŞMA: Serbest doku aktarımının çocuklardaki avantajları arasında yer alan çocuğun daha iyi flep büyümesine adaptasyonu ve çocuğun öğrenme kapasitesi sayesinde cerrahlar daha iyi ve fonksiyonel ve estetik sonuçlar sağlamaktadırlar.

Anahtar sözcükler: Serbest doku aktarımı, çocuk hasta popülasyonu, perforatör flepler.

Ulus Travma Acil Cerr Derg 2013;19(5):41 I-416 doi: 10.5505/tjtes.2013.095।5 